Published as: De Wulf, A., De Maeyer, P., Stal, C. \& Vandenbulcke, A. (2015). The demand for hydrographic surveyors in the Benelux. Paper presented at the $15^{\text {th }}$ International Multudisciplinary Scientific Geoconference (SGEM), Albena (Bulgaria), 18-24 June 2015, pp. 1053-1060.

\title{
THE DEMAND FOR HYDROGRAPHIC SURVEYORS IN THE BENELUX
}

\author{
Prof. dr. ir. Alain De Wulf ${ }^{1}$
}

Prof. dr. Philippe De Maeyer ${ }^{1}$

Dr. Cornelis Stal ${ }^{1,2}$

MSc. Annelies Vandenbulcke ${ }^{1}$

${ }^{1}$ Ghent University, Department of Geography, Belgium

${ }^{2}$ Ghent University College, Department of Real Estate and Land Surveying - Belgium

\begin{abstract}
In February 2015, the Hydrographic Society Benelux (HSB) sent an extended questionnaire to 77 of the most important hydrographic companies in the Benelux (Belgium, The Netherlands and Luxemburg). The organization of this questioning was in cooperation with the Department of Geography of Ghent University (Belgium). The purpose was to inquire the demand for hydrographic surveyors during the next 5 years in the Benelux. The Benelux is hosting the four biggest dredging companies in the world, so the demand for hydrographic surveyors is usually fairly high and a good parameter for the general demand in the West of Europe.

On the one hand, the aim of the questionnaire was to research the demand for the preferred level of hydrographic surveyor, allowing a concise estimation of the demand for IHO category-A and category-B certified hydrographic surveyors. On the other hand, the required balance between hydrographic surveyors with a Bachelor versus Master degree was questioned. As a similar questionnaire and analysis has been performed in 2009, trends over the past 6 years can be discerned and analyzed. The results are important, not only for the private companies, but also for the higher education institutes. In the Benelux, but also outside the Benelux, one can find hydrographic institutes delivering cat. A and cat. B. IHO certified hydrographic surveyors, combined or not with a Bachelor and/or Master diploma.

It is generally assumed that there is a shortage of hydrographic surveyors and/or of hydrographical educated employees in the Benelux. Currently, part of the active hydrographic surveyors in the Benelux are engineers, geologists and other non-
\end{abstract}


specifically hydrographic trained people, who received additional bathymetric training within private companies. But does this hypothesis withstands a scientific analysis? This will be critically analyzed in this paper.

Key words: Hydrography, Hydrographic Surveyors, Employment

\section{INTRODUCTION}

The employment enquiry study for the Benelux was carried out by Ghent University (Belgium) in cooperation with the Hydrographic Society Benelux (HSB) in January 2015. The need for an enquiry emerged from the Hydrographic Society Benelux [1] that wanted an update of a similar survey (internal report) carried out in 2009 by Annelies Claeys. This demand for a survey was supported by Ghent University, that started a postgraduate programme "Hydrography IHO cat. B" [2] on the 17th of September 2012, as a collaboration between Ghent University and the Institute for Hydrography of the Antwerp Maritime Academy as hosting institute. This program received its International Hydrographic Organization (IHO) cat. B accreditation in April 2013 [3], providing an answer on the large need for trained hydrographic surveyors [4,5]. A programme with cat. $\mathrm{A}$ is under study. The 1-year program (Figure 1) consists of 4 theoretical modules of 3 weeks each, fitted in a two-semester system. Between the theoretical modules, the fieldwork is planned. At the end of each semester, a two week study period followed by an examination period, is included.

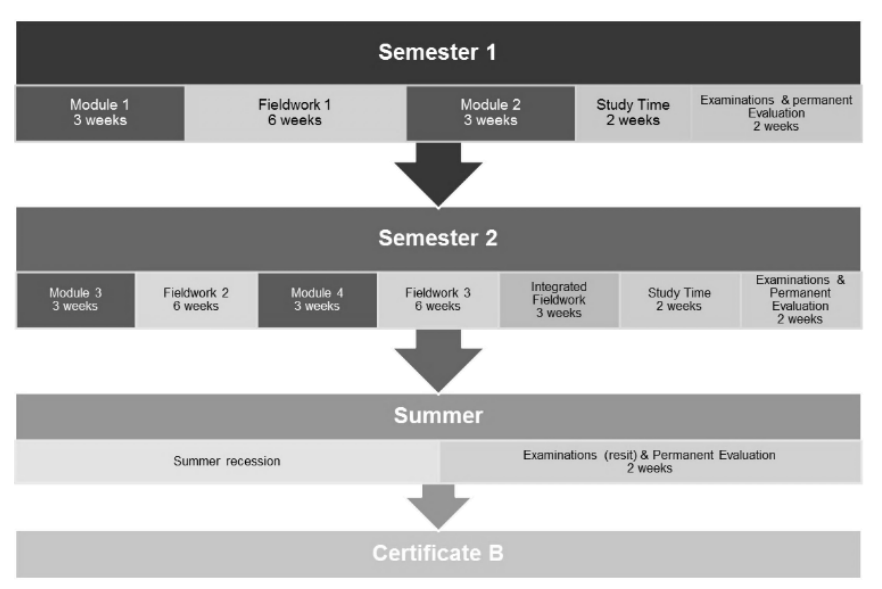

\begin{tabular}{|c|c|c|c|c|}
\hline & Course Title & ECTS & $\begin{array}{l}\text { Class } \\
\text { Hours }\end{array}$ & Location \\
\hline 1 & ICT & 3 & 24 & UGent \\
\hline 2 & Navigation & 6 & 48 & HZS \\
\hline 3 & Safety & 3 & 24 & HZS \\
\hline 4 & Seamanship & 3 & 24 & HZS \\
\hline 5 & Tides and Currents & 3 & 24 & HZS \\
\hline 6 & Hydrographic Surveying & 6 & 48 & UGent \\
\hline 7 & $\begin{array}{l}\text { Geodesy and } \\
\text { Cartography }\end{array}$ & 3 & 24 & UGent \\
\hline 8 & Data Management & 3 & 24 & UGent \\
\hline 9 & $\begin{array}{l}\text { Geology and } \\
\text { Geophysics }\end{array}$ & 3 & 24 & UGent \\
\hline \multirow[t]{2}{*}{10} & Legal Aspects & 3 & 24 & UGent \\
\hline & $\begin{array}{l}\text { TOTAL THEORETICAL } \\
\text { CLASSES }\end{array}$ & 36 & 288 & \\
\hline
\end{tabular}

Figure 1. - 1-year program of postgraduate in Hydrography cat. B

Figure 2. - Theoretical courses in the cat. B program

The location of the theoretical courses is divided between the campus of the Antwerp Maritime Academy (HZS) and the campus of Ghent University (UGent), with a relatively fast access between both institutes (ca. $45 \mathrm{~min}$. travel time by easy public or private travelling). Furthermore, both locations are never used the same day. As can be seen from figure 2, the navigation related topics are taught at the HZS while the geodesy, data management, geology and ICT related topics are provided by the Geography, Geology and Informatics Departments at the UGhent. More details of the 
program can be found in [6]. International cooperation in education programs was assured as in 2012, 2013 and 2014, when the students were offered the possibility to participate in an "European Union Erasmus Intensive Program" which aimed at providing intensive courses and at organizing a hydrographic and topographic surveying camp jointly proposed by European universities, ENSTA Bretagne (France)[7], UGent (Belgium) and HCU University (Germany)[8], and the CIDCO (Interdisciplinary Centre for the Development of Ocean Mapping) (Canada), as an associate partner,. This project took place at the "Lake of Vassivière", one of France's largest artificial lakes exploited by EDF, France's global energy company and was coordinated by Prof. Nicolas Seube (ENSTA). Between 30 and 50 students in total were tasked to achieve the survey instructions given by EDF like in a real professional context.

As the number of students for the Belgian cat. B program remained under the forecasted level of more than 20 students a year, a new analysis of the demand for cat. B. certified hydrographic surveyors was desirable, as well as special focus on the evolution of the demand for hydrographic surveyors between 2009 and 2015 and on the difference between the situation in The Netherlands and in Belgium. In Luxemburg, there are actually no HSB members, presumably due to a lack of hydrographic companies in this area.

\section{METHODOLOGY}

The enquiry with 27 questions was sent in January 2015 by e-mail to the 52 corporate members of the Hydrographic Society Benelux in the Netherlands and the 9 corporate members in Belgium. The response level, with $37 \%$ in the Netherlands and $67 \%$ in Belgium, was good, as all major hydrographic companies (especially dredging companies) responded. The responding companies employ a total of 548 hydrographic surveyors in the Netherlands and 307 hydrographic surveyors in Belgium. It can be assumed that these companies cover more than $75 \%$ of the total employment of hydrographic surveyors in the Benelux. Compared to the survey of 2009, no engineering or land contractors responded, because the survey was not sent in 2015 to geo-business group members, as the total amount of hydrographic surveyors used by these companies is very limited. The "other" group in 2015 includes companies involved in software/hardware, offshore installations, geophysical services or harbour exploitation.

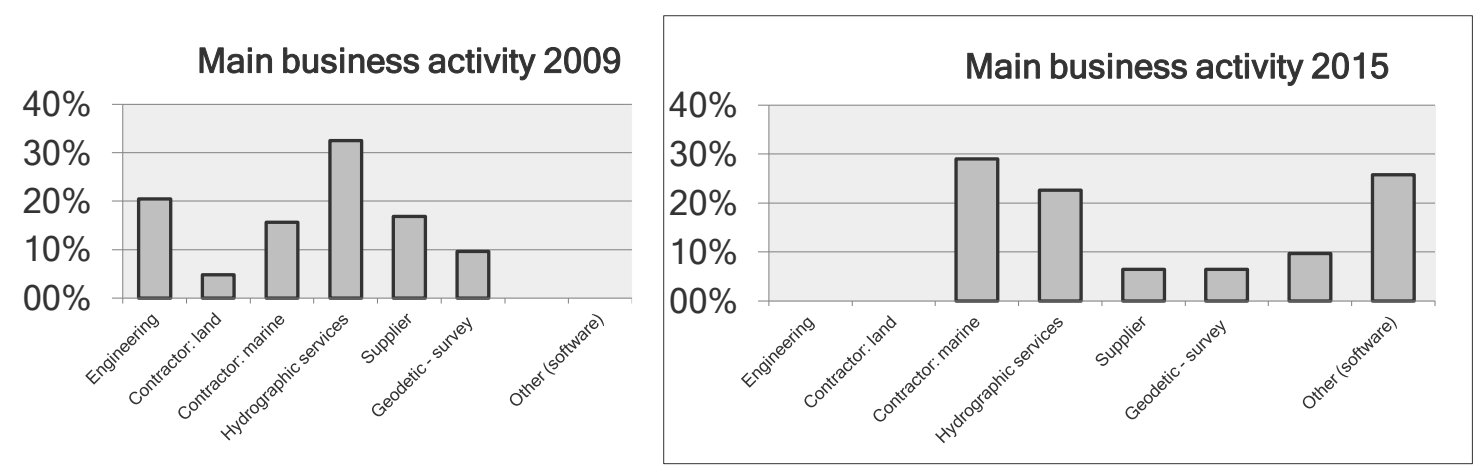

Figure 3. - Main business activity of responding companies 
Typically, a larger number of companies employs a smaller number of hydrographic surveyors in the Netherlands than in Belgium: ca. $50 \%$ of the companies have 5 or less hydrographic surveyors in the Netherlands, while the restricted number of companies in Belgium employ more hydrographic surveyors (the two dredging companies count for $33 \%$ and employ each approx. 150 surveyors)(fig.

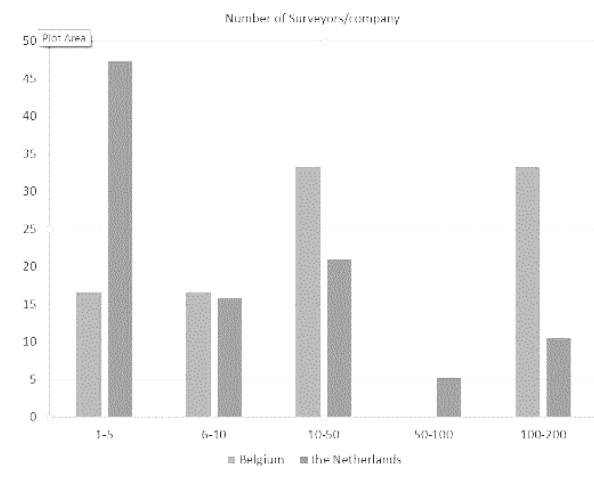
$4)$.

Figure 4. - Number of hydrographic surveyors/company (Belgium=left, The Netherlands= right)

\section{RESULTS RELATED TO THE HYDROGRAPHIC EDUCATION PROGRAMS}

The employment of hydrographic surveyors by private companies in the Benelux is related to the knowledge of the hydrographic education opportunities. Therefore, a set of questions was aimed at assessing the perception of the different education options available: In the Benelux, one will find three hydrographic education options(fig.5):

1) A "IHO cat. A hydrography" offered by the "Maritime Institute Willem Barentsz" (Terschelling, the Netherlands) [9];

2) A "IHO cat. B hydrography" offered by the private company "Skilltrade" [10];

3) A "IHO cat. B hydrography" offered by the "Antwerp Maritime

(Antwerpen, Academy together with Ghent University [2].

Do you know ?

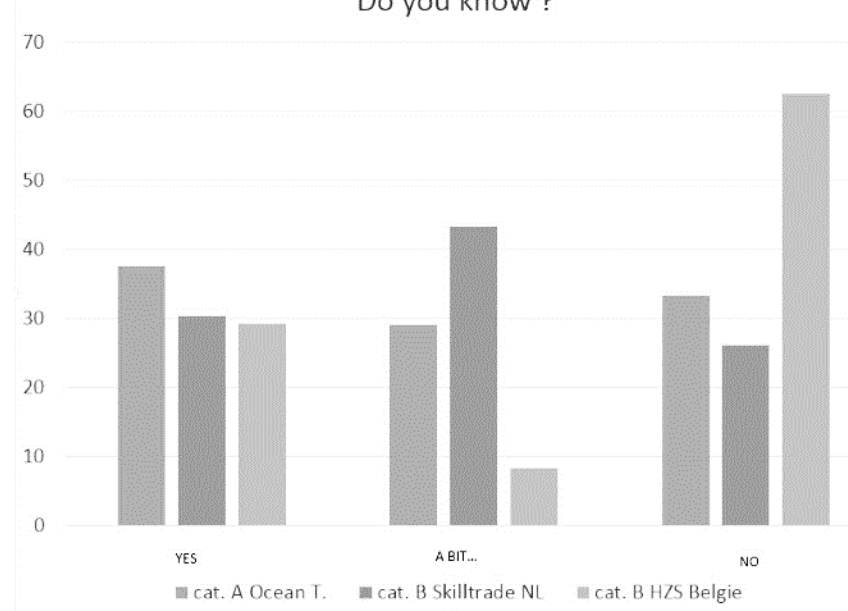

Figure 5. Do you know the hydrographic education programs [\%\} (left=cat.A Ocean T., mid=cat. B. Skilltrade, right=cat. B Belgium)

An interesting question was "As there is a tight relation between geomatics/geodesy and hydrography, is cooperation between both education programs an option ?" Almost 90 $\%$ responded positively to this question.

To the question "Do you advise to include more hydrography in non-hydrographic education programs such as geomatics, dredging technology, civil engineering, maritime officer, geophysics, water management,...", more than $95 \%$ responded affirmatively.

Finally we enquired on the best ways to promote hydrographic education in the society. As could be expected, internet is nowadays the preferred way. 
Opportunities to promote hydrography (2009 - 2015)

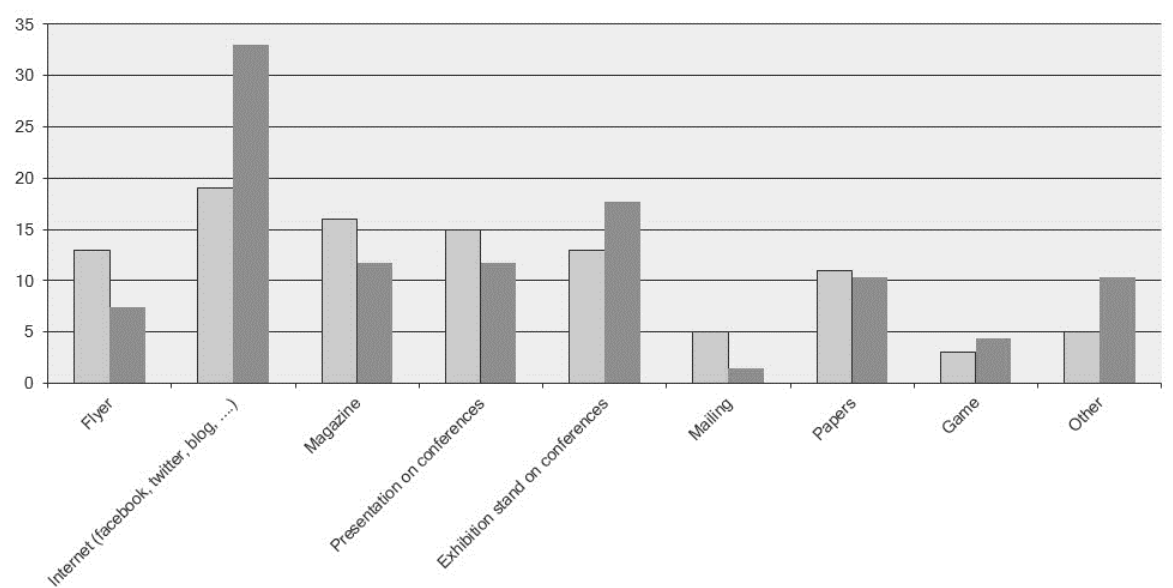

Figure 6. What are the best ways to promote hydrographic education programs (left=2009, right=2015)?

\section{RESULTS RELATED TO THE DEMAND FOR HYDROGRAPHIC SURVEYORS}

The first and most obvious question is the total number of hydrographic surveyors that the responding private companies expect to hire in a 2-year, 5-year and 10-year future, both in absolute numbers per year and in percentage of the actual population of hydrographic surveyors (fig. 7).
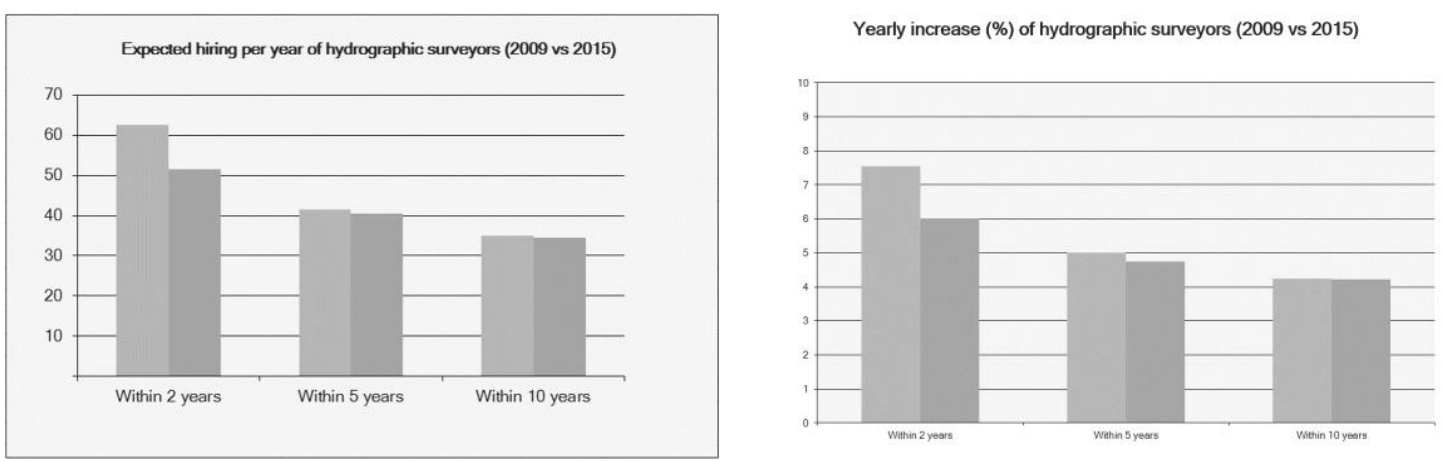

Figure 7. Expected hiring per year of hydrographic surveyors (absolute number and $\%)(l e f t=2009$, right $=2015)$

As can be derived, the actual situation in 2015 is a bit less optimistic than in 2009 , especially on the short (2-year) term. In that respect, it is worthwhile to compare the prediction for 2015 made in 2009 with the actual situation in 2015 (fig. 8). As can be seen, the actual situation is slightly worse than expected in 2009 , presumably due to the economic and financial problems in

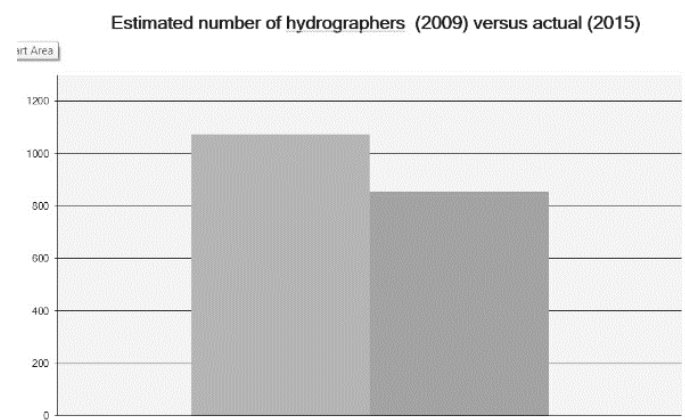
Europe during the last 5 years. 
Figure 8. Expectation for 2015 based on the 2009 survey (left) versus the actual situation in 2015 (right)

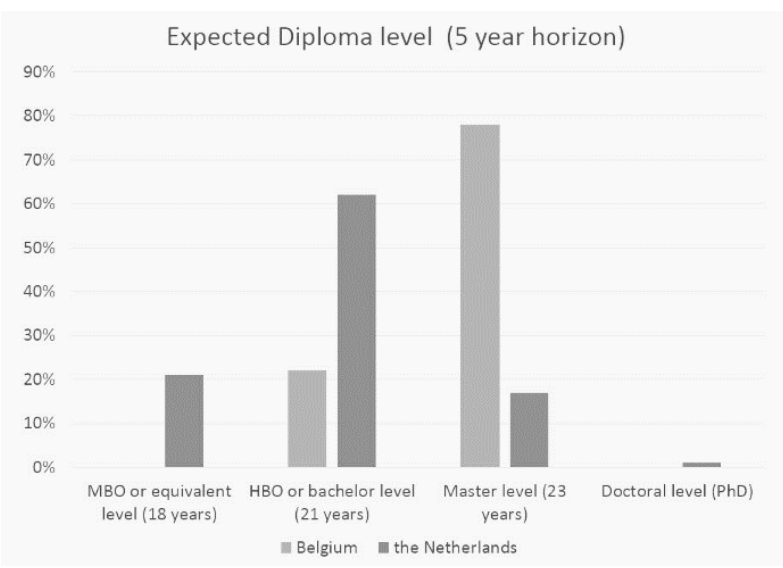

student).

Figure 9. Required diploma level for hydrographic surveyors

(5-year horizon) in Belgium and the Netherlands.
What is the required diploma level of the hydrographic surveyors that will be hired during the next five years? Here, a very remarkable difference between Belgium and the Netherlands can be discerned. However, it can be explained by the difference in education options. In the Netherlands, the cat. A education option (cfr. above) has a bachelor level, while the cat. B education option is slightly above MBO level (18 years old

In Belgium, the cat. B hydrography education option requires a bachelor degree to start the program. Part of the students even starts with a Master degree. This explains why the output level is certainly higher than bachelor level. Moreover, the dredging companies also hire a significant number of "Master in Geomatics" graduated students. It can therefore be expected that the hired people in Belgium will stay, as now usual, at a Master level or more or less equivalent $(=$ Bachelor + cat. B).

Is a IHO certification needed or wanted for hydrographic surveyors (fig. 10)? The answer is yes for the Netherlands (expected for ca. $85 \%$ of the hired people (5-year horizon), but less stringent in Belgium, where only $2 / 3$ of the hired surveyors are expected to be $\mathrm{IHO}$ cat. A. or cat. B certified.

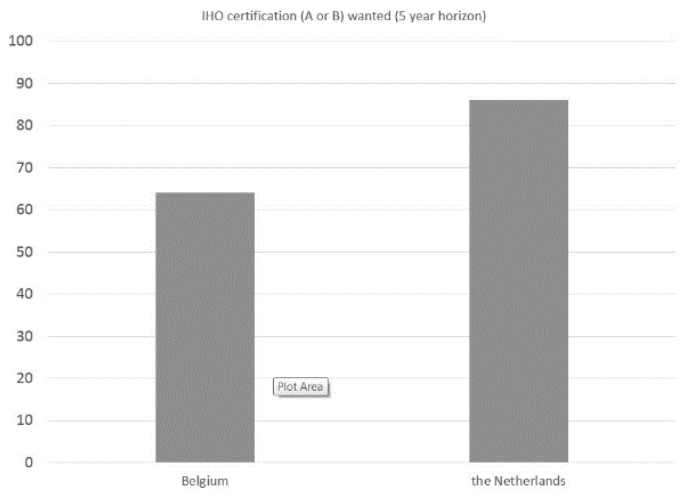

Figure 10. IHO certification wanted (5-year horizon) in Belgium and the Netherlands .

What type of IHO certification is expected: cat. A or cat B. (fig. 11)? For the Benelux, the cat. A surveyor is the most wanted type, but again, the difference between the situation in Belgium and the Netherlands is quite different, presumably due toto the fact that in Belgium only a cat. B hydrography program is available, while in the Netherlands, both types are offered (on a clearly distinct level). 

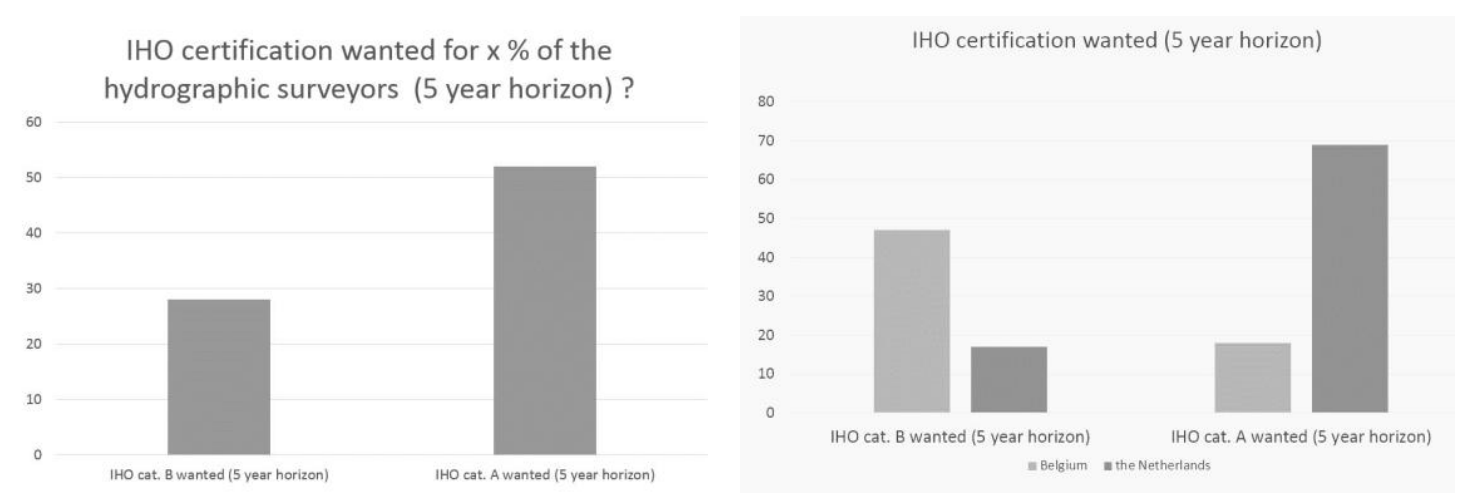

Figure 11. IHO cat. A./ cat. B certification wanted in [\%] for both countries together and separately in Belgium and the Netherlands .

While fig. 11 is expressed in percent, table 1 yields the absolute numbers for both countries. Again, the absolute numbers for the demand for cat. A. hydrographic surveyors differ very significantly in both countries ( 2 per year for Belgium versus 19 per year for the Netherlands). The numbers in fig. 12 are based only on the numbers given by the responding companies, therefore the real numbers may be expected to be slightly (20-40\%) higher.

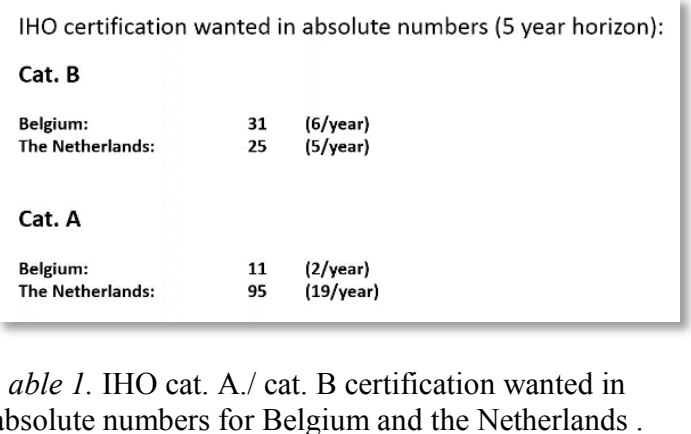

able 1. IHO cat. A./ cat. B certification wanted in
absolute numbers for Belgium and the Netherlands

\section{CONCLUSION}

The demand for hydrographic surveyors in the Benelux has been investigated by an extensive survey, performed in January 2015. A comparison with a former survey performed in 2009 was, for most of the topics, possible in order to extract trends. The following conclusions can be formulated:

1) As the response level of both surveys of 2009 and 2015 is quite similar and may be expected to cover at least $75 \%$ of the hydrographic market, as all bigger private companies are included, it may be assumed that the numbers published in this paper may be considered as valid and reliable.

2) The hydrographic world in the Netherlands is characterised by a big number of smaller companies. In Belgium there are much less hydrographic oriented companies, and especially small hydrographic companies are rare.

3) In Belgium, a IHO cat. B program was started in September 2012. In the Netherlands, a cat. A and a cat. B program were already much longer established. This can explain that the Belgian cat. B. program is less well known than the hydrographic education programs in the Netherlands.

4) In the Netherlands, hydrographic companies expect to hire mostly cat. A. surveyors (19+ per year). A Master level is usually not required. To a lesser 
amount (5+ per year), cat. B surveyors will be hired. Only $15 \%$ of the hired surveyors is expected to not own a cat. A./B. certificate.

5) In Belgium, hydrographic companies expect to hire mostly cat. B. surveyors (6+ per year). A Master level is usually expected. To a lesser amount (2+ per year), cat. A surveyors will be hired. More than a third of the hired surveyors is expected to not own a cat. A./B. certificate, so this certificate is not an absolute requirement.

6) It should be stressed that the differences between the situation in the Netherlands and in Belgium could be explained by the different hydrographic education systems and that the future expectations correlate with the actual education options. Therefore, if the hydrographic education system would evaluate, the corresponding demand could also change significantly. More specifically, if a IHO cat. A hydrography would be started in Belgium, it could be expected that the demand for cat. A surveyors in Belgium would also rise.

7) The common demand for the Benelux is around 50+ hydrographic surveyors per year on a 2-year horizon, slight decreasing till level of 35+ surveyors per year on a 10-year horizon. These future previsions are slightly less optimistic than the situation in 2009, especially on the short term (2-year) basis.

Finally, it would be interesting to compare the results of this survey with these of similar surveys in neighbouring countries such as Germany and France and analyse what the similarities and differences, and the causes for these similarities and differences are.

\section{REFERENCES}

[1] http://www.hydrographicsocietybenelux.eu

[2] http://www.hzs.be/en/other-training/hydrography/introduction

[3] http://www.iho.int/mtg_docs/com_wg/AB/AB_Misc/Recognized_Programmes.pdf

[4] D. DODD, G. JOHNSTON, A. HOGGARTH. The Economic Impact of Appropriate Education in Hydrography, 7th FIG Regional Conference; Hanoi, Vietnam, Oct 2009.

[5] J. GREENFELD. Surveying Body of Knowledge, FIG Congress, Sydney, Australia 2010.1

[6] DE WUlf, A., DE MAEYER, P., DE RYCK, M., NUTTENS, T., STAL, C., LIBERT, M., \& ANNAERT, A. (2013). Higher hydrography education in Belgium. International Multidisciplinary Scientific GeoConference-SGEM (pp. 429-436). 
Presented at the 13th International multidisciplinary scientific Geoconference SGEM (SGEM 2013), Bulgaria: International Scientific Conference SGEM

[7] N. SEUBE, A. DE WULF, V. BÖDER, T. TOUZÉ, N. DEBESE, R. MOITIE, I. PROBST, M. AUDET MORIN, T. NUTTENS, C. STAL (2012), International cooperation in education: the Vassivière Erasmus Intensive Training program (20112013) on hydrography and geomatics. Proceedings of Hydro12: 'Taking care of the sea', Rotterdam, the Netherlands, 13-15 November, p. 8.

[8] V. BODER, D. EGGE. Hydrographic Education (Cat A) at the Newly founded Hafencity University, Hamburg (HCU).6th FIG Regional Conference; San José, CostaRica, Nov 2007.

[9] http://www.nhl.nl/nhl/4016/miwb/opleidingen/ocean-technology.html

[10] http://www.skilltrade.nl/courses/hydrographic-survey-category-b-course 